\title{
S49. Eastern Europe: psychiatry and political changes
}

NEW FACTORS OF PSYCHIC DESADAPTATION UNDER CIRCUMSTANCES OF CURRENT SOCIAL DISTURBANCES

\section{GK Dzub, SV Pchydenko, VB Yesipenko}

Kiev General and Forensic Psychiatry Research Institute, Frunse str. 103, 254072, Kiev, Ukraine.

Dramatic political and economical events occurred in former USSR are reflected in clinical changes of psychic disorders. The causes and characteristics of those changes studying is the goal of this research. 346 patients with psychoses and borderline disorders were examined using clinicbiographical and psychodiagnostic methods. Newly obtained factors of desadaptation are:

(a) changes in business relationship and increase of demands to a person:

(b) economic crisis and weal decrease;

(c) loss of previous value and believes system

due to sudden denial from materialistic ideology

(d) ecological and psychological consequences of Chernobyl disaster:

(e) loss of previous description points in pupils and students.

Some changes in predominant themes of delusional

ideas, the increase of the quantity of asthenic

and depressive states and induced psychic

disorders were found in mentally ill patients. The reduction of patients' social functioning level

and the early occurrence of psychic desadaptation are peculiarities of current situation in

Ukrainian psychiatry.

\section{CREATING POST-COMMUNISTIC MODEL OF PSYCHIATRY IN} LITHUANIA

A.Püras, R.Šrerkšnienè, D.Deltuvienè, G. Čebelis

Psychiatry Clinic of Kaunas Medical Academy, Eivieniu 2. 3000 Kaunas, Lithuania

For 50 years Lithuania suffered the yoke of soviet occupation. During that period it was isolated from the western world. Repressive soviet system formed soviet way of thinking in various areas of life. Human rights were disturbed, often impermissible methods of treatment were used in medicine. Psychiatry especially painfully was affected by all this. The rights of psychiatry patients were disturbed, there was no law, protecting psychiatry patients. Psychiatry was discredited in the eyes of community so as people with another way of thinking, dissidents were put into the psychiatry hospitals.

When Lithuania two years ago gained it's independence, the window to the west opened to Lithuanian psychiatry too. New, useful contacts were established, especially with Scandinavian countries. Now decentralization of psychiatry care and diminishing of the beds in psychiatry is taking place. Psychiatry departments are being opened in general hospitals, psychosomatic departments too. Outpatient psychiatry is tried to be more popular. We try to create in Lithuania a post-soviet model of psychiatry. We are preparing educational programs according the western programs, started educating residents in psychiatry in Lithuania. Children and adults mental health programs, which protect the patients and guarantees the rights to the mentally ill patients and helps to integrate them to the community are being created and admitted.

Lithuanian psychiatrists started taking part in the programs of WHO, in 1993 they were admitted to the worlds association of psychiatrists. 
L'INFLUENCE DU CHANGEMENT POLITIQUE SUR LA PSYCHIATRIE EN BULGARIE

\section{St. Todorov}

L'Université de Médicine, Chaire de Psychiatrie et Psychologie Médicale 55, rue M. Drinov, Varna 9002 , Bulgarie

Comme on sait le régime totalitaire in Bulgarie a tombé la fin de 1989. Celà a découvert le chemin des radicaux changements politiques, sociaux et économiques, qui pourraient mener à l'édification d'une société démocratique, pareille aux sociétés contemporaines occidentaux. Le changement s'avéra un processus continu, d'une manière inattendue, lié à des difficultés énormes d'espèce diverse.

Dans la santé publique et en particulier dans la psychiatrie quoique les vieilles structures en plan général continuent à exister, les priorités nouvelles se forment et on procède d'une manière lente et pénible à leur réalisation.

Une place principale entre les priorités de la psychiatrie occupent la décentralisation de l'aide psychiatrique, l'établissement des rélations adéquates entre le secteur privé et celui de l'Etat, le développement de la psycho- et sociothérapie, la formation des cadres, les problèmes, liés à l'accroissement vite des norcomanies, de l'AIDS, de la prostitution et du chốnage.

Nous nous arrêterons sur cettes questions, en marquant certains aspects des résultats obtenus de l'expérience accumulée durant la collaboration, qui a continuée plus de deux années entre l'Hôpital Cantonal de Liestal (Suisse) et les cliniques de la Chaire de Psychiatrie et Psychologie Médicale chèz l'Université de Médicine - Varna.

THE MAIN EFFECTS OF THE RECENT SOCIAL AND POLITICAL EVENTS ON MENTAL HEALTH OF THE POPULATION AND MENTAL HEALTH CARE IN THE REPUBLIC OF BELARUS F.M. Gaidouk, A.R. Zorko, V.B. Poznyak

Department of Psychiatry of Minsk Medical Institute and Republican Psychiatric Hospital, Dzerzhinskiy Ave. 83, Minsk, 220798, Belarus

Among the positive effects are the following: a) the liberalisation of mental health care; b) the Republic has gained autonomy in the process of the development of appropriate legislative acts and mental health services; c) non-governmental facilities for mental health care has started to set up; d) the professional contacts with other countries are constantly increasing. However, the following negative effects are also obvious: a) the increase of adjustment disorders; b) disintegration of the single scientific and information space of the former USSR; c) the decrease in financing of mental health service; d) acute deficit of psychotropic drugs due to economic problems; e) antipsychiatric movement spreading across the Republic. In the following 5 years the creation of adequate legislation for mental health system, the reform of undergraduate and postgraduate education in psychiatry and restructuring of mental health services are being planned.
L'INCERTITUDE A L'OMBRE DE LA GUERRE: LES PATIENTS "LIBERES" ET LES PSYCHIATRES "PRISONNIERS"

N. Caran, V. Popovic

Institut de la psychiatrie du Centre clinique universitaire, Belgrade, Yougoslavie

Dans un échantillon de 214 patients en clinique externe, traités à Belgrade des années 1993 (109) et 1990 (105), nous avons étudié la correspondence empirique et théorique entre la situation de l'incertitude existentielle permanente et les réactions individuelles chez les (1) nouveaux patients, (2) les anciens patients et (3) les changements des méthodes de traitement psychiatrique. Nous avons utilisé l'interview psychiatrique, les échelles d'Hamilton (pour la dépression et l'anxiété), Comell Index et -pour faire le diagnostic- les critères d'ICD $X$ et DSM III-A.

Les changements de psychopathologie nous avons registré chez les troubles somatoformes et les troubles d'adaptation, aussi chez les états de stress post-traumatique $(p \leq 0.05)$. Les troubles nevrotiques ont baissés et correspondaient à un nouveau type d'adaptation qui nous avons appelé "je dois" (au lieu d'antérieur "je peux" ou "je veux").

Les psychiatres ont perdu leur puissance magique et pour eux, ne reste que (1) "s'immobiliser" ou (2) s'inclure activement dans les courants sociaux (une sorte d'anarchisme éclectique).
THE ROLE OF THE PSYCHOPHARMACOINDUSTRY IN THE EASTWEST RELATIONS: PROBLEMS AND PROSPECTIVES

P.Morozov', A. Maertens' ${ }^{2}$ J. Litvishenko ${ }^{3}$

'Knoll AG, Moscow, ${ }^{2}$ Organon Int., Moscow, ${ }^{3}$ Rhône Poulenc Rorer, Moscow

In the last few years many Western pharmaceutical companies have entered the Russian market. At present they face a wide range of problems among which are: economic and political instability; permanent changes in the infrastructures of drugs sales, poor distribution network; approach different to the western standard towards medicine especially in the field of psychiatry.

The following joint strategy was suggested to contribute in solving the above mentioned problems.

1. To introduce in Russia new drugs of high western quality (registration and clinical trials)

2. To provide good product information to the medical profession (conferences, seminars, exhibitions)

3. To make new drugs of high western quality available on the eastern market (joint production and opening of consignment stocks)

in perspective, simpler registration procedure should be discussed with the Russian Ministry of Health for products which have already been registered in Western Europe and North America.

Taking into consideration low purchasing power of the psychic patients, the possibility or reimbursement of psychotropics in Russia should be discussed within governmental circles. 
EAST MEETS WEST:

COMMON DILEMMAS FOR THE PSYCHIATRIC PROFESSION.

Marianne Kastrup, M.D.

Hvidovre Hospital, University of Copenhagen, Dept. of Psychiatry,

Broendbyoestervej 160, DK-2650 Hvidovre, DENMARK

The role and obligations of the psychiatrist as an individual and a world citizen do not differ between East and West. The individual ethical challenge refers to the psychiatrist as a professional, a "doctor at risk". This includes situations and circumstances in which the psychiatrist in his professional capacity may find himself in a therapeutic or research dilemma forcing him to take an ethical stand.

As citizens psychiatrists also have an obligation to work for a more equal access to mental health services for all in need hereof irrespective of ethnic background, social status, age or sex.

Indicators of inequalities in psychiatric morbidity should be developed, and investigations of the effect of the implementation of different health policy programmes are called for.

The major ethical challenges our profession is facing will be discussed. 